\title{
KONTRIBUSI ETOS KERJA ISLAMI DAN PELATIHAN TERHADAP KINERJA GURU MADRASAH TSANAWIYAH SWASTA (MTSS) SE-KOTA PADANG PANJANG
}

Asrizallis

Guru Pondok Pesantren Tawalib Gunung Kota Padang Panjang, Sumatera Barat Ema il: a srizalliszein@gmail.com

$+20$

\begin{abstract}
In this quantitative study the researcher tested three hypotheses 1) the work ethos of Islamic contributed significantly toward the teachers' job performance; 2) the training contributed significantly toward the teachers' job performance; 3) simultaneously, the work ethos of Islamic and training contributed significantly toward the teachers' job performance in Islamic Junior High School Padang Panjang. Research samples were 58 teachers which were selected from 152 population. Research data were collected through questionnaire. The results revealed that a) the work ethos of Islamic contributed significantly (26,50\%) toward the teachers' job performance; b) the teachers' training contributed significantly (26,00\%) toward the teachers' job performance; $c$ ) simultaneously, the work ethos of Islamic and training contributed significantly (40,70\%) toward the teachers' job performance.
\end{abstract}

Keywords: Teachers' Job Performance, Work Ethos of Islamic, Training, Islamic Junior High School

\section{PENDAHULUAN}

Madrasah Tsanawiyah Swasta (MTsS) memiliki tanggung jawab untuk mengembangkan sumber daya manusia (peserta didik), di mana guru adalah sebagai ujung tombak dalam dunia pendidikan yang dituntut memiliki kompetensi untuk membawa siswa kepada suatu keberhasilan. Dalam Undang-Undang No. 14 tahun 2005 tentang guru dan dosen, pasal 10 menyatakan "kompetensi yang harus dimiliki oleh seorang guru meliputi kompetensi pedagogik, kompetensi kepribadian, kompetensi professional dan kompetensi sosial". Berdasarkan hal tersebut dapat dikatakan bahwa tugas seorang guru bukanlah pekerjaan mudah untuk dilakukan.

Untuk memiliki kinerja yang baik, guru hendaknya memiliki beberapa kompetensi yang akan digunakan dalam melaksanakan tugasnya sebagai seorang pendidik. Berdasarkan Peraturan Menteri Pendidikan Nasional Republik Indonesia Nomor 16 Tahun 2007 tentang Standar Kualifikasi Akademik dan Kompetensi 
Guru dijelaskan bahwa standar kompetensi guru dikembangkan secara utuh dari 4 kompetensi utama, yaitu (1) kompetensi pedagogik, (2) kompetensi kepribadian, (3) kompetensi sosial, dan (4) kompetensi profesional (Djamaan, 2008). Keempat kompetensi tersebut terintegrasi dalam kinerja guru.

Peranan etos kerja Islami dan Pelatihan juga sangat penting dalam meningkatkan kinerja guru, sebagai contoh seorang guru yang memiliki kinerja baik sebaiknya mendapatkan apresiasi yang positif dari kepala sekolah dan kalau perlu diberikan penghargaan agar kinerja guru yang bersangkutan semakin meningkat. Sebaliknya bagi guru yang berkinerja rendah tentunya harus mendapatkan pembinaan dari kepala sekolah. Tujuan pemberian pembinaan/ pelatihan adalah untuk memberikan pembinaan agar terjadi perubahan kinerja guru yang bersangkutan ke arah yang lebih baik.

Masalah yang ditemukan dalam penelitian ini melalui observasi antara lain a) tanggung jawab guru terhadap tugasnya (etos kerja) masih rendah; b) pemikiran guru yang kurang rasional terhadap tugasnya; c) kerja keras guru masih rendah; dan d) guru masih kurang mengerti dalam merumuskan tujuan pembelajaran, membuat instrumen penilaian hasil belajar. Oleh karena itu penelitian ini bertujuan untuk menemukan apakah etos kerja islami dan pelatihan berkontribusi terhadap kinerja guru Madrasah Tsanawiyah Swasta (MTsS) se-Kota Padang Panjang.

\section{PENGERTIAN KINERJA GURU}

Kinerja menurut Mangkunegara (2010: 210) berasal dari kata Job Performance atau Actual Performance (prestasi kerja atau prestasi sesungguhnya yang dicapai seseorang). Kinerja (prestasi kerja) adalah hasil kerja secara kualitas dan kuantitas yang dicapai oleh seorang pegawai dalam melaksanakan tugasnya sesuai dengan tanggung jawab yang diberikan kepadanya.

Kinerja tenaga pengajar adalah menyangkut seluruh aktivitas yang ditunjukkan oleh tenaga pengajar dalam tanggungjawabnya sebagai orang yang mengemban suatu amanat dan tanggungjawab untuk mendidik, mengajar, membimbing, mengarahkan, dan memandu peserta didik dalam rangka menggiring perkembangan peserta didik ke arah kedewasaan mental-spiritual maupun fisikbiologis. Kinerja pengajar adalah perilaku atau respons yang memberi hasil yang mengacu kepada apa yang mereka kerjakan ketika dia menghadapi suatu tugas. Kinerja 
tenaga pengajar menyangkut semua kegiatan atau tingkah laku yang dialami tenaga pengajar, jawaban yang mereka buat untuk memberi hasil atau tujuan.

Menurut Mulyasa (2009: 139) faktorfaktor yang mempengaruhi produktivitas kerja dalam melaksanakan tugasnya adalah a) sikap mental; b) pendidikan; c) keterampilan; d) manajemen; e) hubungan indrustrial; f) tingkat penghasilan; g) gizi dan kesehatan; h) jaminan sosial; i) lingkungan dan suasana kerja; j) kualitas sarana; k) teknologi; dan l) kesempatan berprestasi.

Penilaian atas kinerja guru didasarkan atas Peraturan Menteri Pendidikan Nasional Republik Indonesia (Permendiknas) No. 16 tahun 2007 tentang Standar Kompetensi Guru yaitu meliputi empat kompetensi, Yamin dan Maisah (2010: 56) menyebutkan keempat jenis kompetensi tersebut yaitu, a) kompetensi pedagogik; b) kompetensi profesional; c) kompetensi kepribadian; dan d) kompetensi sosial.

Upaya-upaya yang dapat dilakukan sekolah dalam upaya meningkatkan kinerja tenaga kependidikan dan prestasi belajar peserta didik antara lain sebagai berikut (Mulyasa, 2009: 100), a) mengikutsertakan guru-guru dalam penataran-penataran; b) Kepala Sekolah harus berusaha menggerakkan tim evaluasi hasil belajar peserta didik untuk lebih giat bekerja; c) menggunakan waktu belajar secara efektif di sekolah.

\section{ETOS KERJA ISLAMI}

Menurut Al-Ghazali dalam bukunya "Ihya-u "ulumuddin" yang di kutip Ali Sumanto Al-Khindi dalam bukunya Bekerja Sebagai Ibadah, menjelaskan pengertian etos (khuluk) adalah suatu sifat yang tetap pada jiwa, yang dari padanya timbul perbuatanperbuatan dengan mudah dengan tidak membutuhkan pemikiran.

Ciri-ciri orang yang memiliki semangat kerja, atau etos yang tinggi, dapat dilihat dari sikap dan tingkah lakunya, di antaranya, a) orientasi ke masa depan; b) kerja keras dan teliti serta menghargai waktu; c) bertanggung jawab; d) hemat dan sederhana; dan e) adanya iklim kompetisi atau bersaing secara jujur dan sehat.

\section{PELATIHAN}

Sumantri (2000: 2) mengartikan pelatihan sebagai "proses pendidikan jangka pendek yang menggunakan cara dan prosedur yang sistematis dan terorganisir. Menurut Marzuki (1992: 5) pelatihan adalah suatu proses membantu orang lain dalam memperoleh skill dan pengetahuan. Isi program (program content) merupakan perwujudan dari hasil penilaian kebutuhan 
dan materi atau bahan guna mencapai tujuan pelatihan. Isi program ini berisi keahlian (keterampilan), pengetahuan dan sikap yang merupakan pengalaman belajar pada pelatihan yang diharapkan dapat menciptakan perubahan tingkah laku. Pengalaman belajar dan atau materi pada pelatihan harus relevan dengan kebutuhan peserta maupun lembaga tempat kerja. Nasution (1982: 71) menegaskan "pelatihan adalah suatu proses belajar mengajar dengan mempergunakan teknik dan metode tertentu, guna meningkatkan keterampilan dan kemampuan kerja seseorang. Di mana tujuan pelatihan untuk meningkatkan produktivitas".

\section{METODE PENELITIAN}

Populasi dari penelitian ini adalah 152 orang guru Madrasah Tsanawiyah Swasta (MTsS) se-Kota Padang Panjang. Sampel dalam penelitian ini diambil dengan menggunakan teknik menurut Cochran, stratified proportional random sampling, Jumlah sampel penelitian sebanyak 58 orang guru Madrasah Tsanawiyah Swasta (MTsS) se- Kota Padang Panjang. Metode Pengumpulan data dilakukan melalui angket dengan menggunakan skala likert. Data penelitian dianalisis dengan menggunakan teknik korelasi dan regresi. Analisa data dilakukan dengan menggunakan bantuan program komputer SPSS versi 17.

\section{HASIL PENELITIAN DAN PEMBAHASAN}

Data variabel kinerja guru Madrasah Tsanawiyah (MTsS) se-Kota Padang Panjang diperoleh dari 46 butir pernyataan. Idealnya skor variabel kinerja guru Madrasah Tsanawiyah (MTsS) se-Kota Padang Panjang adalah 230, skor variabel kinerja guru menyebar antara 149 (terendah) dan 176 (tertinggi). Selanjutnya diperoleh skor ratarata (mean) sebesar 163,12, skor tengah (median) sebesar 162,00, skor yang banyak muncul (mode) 166 dan simpangan baku (standard deviation) 7,029. Selanjutnya tingkat pencapaian responden pada variabel kinerja guru Madrasah Tsanawiyah Swasta (MTsS) se-Kota Padang Panjang diperoleh 70,92\%. Capaian ini termasuk kategori Cukup. Dari data ini dapat dikatakan bahwa kinerja guru Madrasah Tsanawiyah Swasta (MTsS) se-Kota Padang Panjang pada umumnya berada dalam kategori Cukup.

Data variabel etos kerja islami guru Madrasah Tsanawiyah ( MTsS) se-Kota Padang Panjang diperoleh dari 41 butir pernyataan. Idealnya skor variabel Etos Kerja Islami adalah 205, Skor etos kerja islami guru Madrasah Tsanawiyah (MTsS) seKota Padang Panjang menyebar antara 118 
(terendah) dan 155 (tertinggi). Selanjutnya diperoleh skor rata-rata (mean) sebesar 132.88 skor tengah (median) sebesar 131.00 skor yang banyak muncul (mode) 129 dan simpangan baku (standard deviation) 10.009 Selanjutnya tingkat pencapaian responden pada variabel etos kerja islami guru Madrasah Tsanawiyah Swasta (MTsS) se-Kota Padang Panjang diperoleh 64,82\%. Capaian ini termasuk kategori Cukup. Dari data ini dapat dikatakan bahwa kinerja guru Madrasah Tsanawiyah Swasta (MTsS) seKota Padang Panjang pada umumnya berada dalam kategori Cukup.

Data variabel pelatihan guru Madrasah Tsanawiyah (MTsS) se-Kota Padang Panjang diperoleh dari 27 butir pernyataan. Idealnya skor variabel Pelatihan Guru Madrasah Tsanawiyah (MTsS) se-Kota Padang Panjang adalah 135, Skor variabel pelatihan guru Madrasah Tsanawiyah (MTsS) se-Kota Padang Panjang menyebar antara 83 (terendah) dan 119 (tertinggi). Selanjutnya diperoleh skor rata-rata (mean) sebesar 102,29 skor tengah (median) sebesar 104, skor yang banyak muncul 108 (mode) dan simpangan baku 9,073 (standard deviation). Selanjutnya tingkat pencapaian responden pada variabel pelatihan guru Madrasah Tsanawiyah Swasta (MTsS) se-Kota Padang Panjang diperoleh 75,77\%, capaian ini termasuk kategori Cukup. Dari data ini dapat dikatakan bahwa pelatihan guru Madrasah Tsanawiyah Swasta (MTsS) seKota Padang Panjang pada umumnya berada dalam kategori Cukup.

Dalam penelitian ini hipotesis yang pertama diajukan adalah etos kerja islami berkontribusi terhadap kinerja guru. Dasar pengambilan keputusan adalah $\mathrm{H}_{\mathrm{O}}$ diterima jika nilai signifikasi $>$ Alpha 0,05 atau $\mathrm{H}_{1}$ diterima jika nilai signifikasi <Alpha 0,05 . Angka koofisien variabel etos kerja islami terhadap variabel kinerja guru (ry.1) sebesar 0,515. Angka korelasi ini menunjukkan bahwa terdapat kontribusi yang positif dan cukup kuat antara etos kerja islami $\left(X_{I}\right)$ terhadap kinerja guru $(Y)$. Angka koofisien determinasi sebesar 0,265 dengan signifikasi sebesar 0,000 , sesuai dengan pengambilan keputusan di atas, maka $\mathrm{H}_{\mathrm{O}}$ di tolak dan $\mathrm{H}_{1}$ diterima. Ini berarti terdapat kontribusi yang signifikan antara etos kerja Islami terhadap kinerja guru Madrasah Tsanawiyah Swasta (MTsS) di Kota Padang Panjang sebesar 26,5\%. Dengan kata lain, 26,5\% Kinerja guru Madrasah Tsanawiyah Swasta (MTsS) di Kota Padang Panjang ditentukan oleh etos kerja Islami.

Hipotesis kedua yang diajukan dalam penelitian ini adalah "pelatihan berkontribusi terhadap kinerja guru". Diketahui bahwa terdapat kontribusi yang positif dan signifikan antara pelatihan terhadap kinerja 
guru. Besarnya koefisien korelasi $r x_{2} \cdot y=$ 0,510 dan koefisien determinasi $\left(r^{2}\right)$ sebesar 0,260 .

Dari temuan ini dapat disimpulkan bahwa pelatihan mempunyai kontribusi yang berarti sebesar 26,0\% terhadap kinerja guru. Dengan kata lain 26,0\% Pelatihan mempunyai kontribusi terhadap variabel kinerja guru, sedangkan sisanya sebesar $74,0 \%$ dipengaruhi oleh variabel lain.

Hipotesis ketiga yang diajukan adalah "etos kerja islami dan pelatihan secara bersama-sama berkontribusi terhadap kinerja guru". Dari hasil analisis diketahui bahwa bahwa besarnya harga koefisien korelasi ganda antara variabel $X_{1}$, dan $X_{2}$ dengan $Y$ (Ry.12) sebesar 0,638 dan koefisien determinasi 0,407. Maka Etos kerja Islami dan Pelatihan secara bersamasama memiliki kontribusi terhadap Kinerja Guru adalah 40,7\%.

Setelah dilakukan pengamatan yang sistematis dan prosedural melalui penelitian dengan menggunakan metode ilmiah, di mana pengukuran menggunakan instrumen yang terlebih dahulu diuji cobakan kepada 29 orang guru yang berada di dalam populasi di luar sampel, setelah dilakukan uji coba didapatkan instrumen yang tidak valid, kemudian instrumen yang tidak valid tersebut dibuang. Kemudian peneliti mengunakan instrumen yang valid untuk melakukan penelitian kepada 58 orang guru Madrasah Tsnawiyah Swasta (MTsS) se-Kota Padang Panjang.

Berdasarkan hasil analisis deskripsi data dan tingkat pencapaian responden guru-guru Madrasah Tsnawiyah Swasta (MTsS) se-Kota Padang Panjang terhadap setiap variabel yang diukur, maka peneliti menemukan hasil penelitian di mana tingkat pencapaian responden tentang kinerja guru Madrasah Tsnawiyah Swasta (MTsS) se-Kota Padang Panjang ternyata berada pada kategori cukup (70,92\%), etos kerja Islami guru Madrasah Tsnawiyah Swasta (MTsS) se-Kota Padang Panjang ternyata berada pada kategori cukup/sedang yaitu (64,82\%), begitu pula dengan pendidikan dan pelatihan guru Madrasah Tsnawiyah Swasta (MTsS) se-Kota Padang Panjang berada pada kategori cukup/ sedang, yaitu $(75,77 \%)$.

Adapun besarnya kontribusi etos kerja islami terhadap kinerja guru Madrasah Tsnawiyah Swasta (MTsS) se-Kota Padang Panjang adalah 26,50\%, kontribusi pelatihan terhadap kinerja guru Madrasah Tsnawiyah Swasta (MTsS) se-Kota Padang Panjang adalah 26,00\%, dan apabila secara bersamasama antara etos kerja islami dan pelatihan terhadap kinerja guru Madrasah Tsnawiyah Swasta (MTsS) se-Kota Padang Panjang 
memiliki pengaruh yang berarti yaitu sebesar $40,70 \%$.

Kontribusi etos kerja islami dan pelatihan terhadap kinerja guru Madrasah Tsnawiyah Swasta (MTsS) se-Kota Padang Panjang dapat diterima dan telah teruji pada tarap kepercayaan 95\%. Selanjutnya dapat diinterprentasikan bahwa etos kerja islami dan pelatihan berkontribusi terhadap kinerja guru Madrasah Tsnawiyah Swasta (MTsS) seKota Padang Panjang sebesar 40,70\%. Hal ini menunjukkan bahwa 40,70\% Kinerja Guru Madrasah Tsnawiyah Swasta (MTsS) se-Kota Padang Panjang dipengaruhi oleh etos kerja islami dan pelatihan. Dengan kata lain secara simultan kedua faktor tersebut mempunyai kontribusi terhadap kinerja guru Madrasah Tsnawiyah Swasta (MTsS) se-Kota Padang Panjang.

\section{KESIMPULAN}

Etos kerja islami berkontribusi secara positif dan signifikan terhadap kinerja guru Madarasah Tsanawiyah Swasta (MTsS) se-Kota Padang Panjang, adapun besarnya koofisien korelasinya sebesar 0,515 dan besarnya kontribusi etos kerja islami terhadap kinerja guru Madarasah Tsanawiyah Swasta (MTsS) se-Kota Padang Panjang adalah 26,50\%. Pelatihan berkontribusi secara positif dan signifikan terhadap kinerja guru
Madarasah Tsanawiyah Swasta (MTsS) se-Kota Padang Panjang, adapun besarnya koofisien korelasinya sebesar 0,510 dan besarnya kontribusi pelatihan terhadap kinerja guru Madarasah Tsanawiyah Swasta (MTsS) se-Kota Padang Panjang adalah 26,00\%. Kontribusi etos kerja islami dan pelatihan secara bersama-sama terhadap kinerja guru Madarasah Tsanawiyah Swasta (MTsS) seKota Padang Panjang berpengaruh positif dan signifikan, adapun besarnya koofisien korelasinya sebesar 0,638 dan besarnya kontribusi etos kerja islami dan pelatihan secara bersama-sama terhadap kinerja guru Madarasah Tsanawiyah Swasta (MTsS) seKota Padang Panjang adalah 40,70\%.

\section{IMPLIKASI}

Semakin tinggi etos kerja islami dan semakin tinggi pelatihan maka diharapkan semakin tinggi juga kinerja guru. Implikasinya adalah jika kinerja guru Madarasah Tsanawiyah Swasta (MTsS) seKota Padang Panjang berada pada kategori cukup ingin ditingkatkan lebih optimal, maka upaya yang dilakukan adalah dengan meningkatkan secara optimal etos kerja islami guru dan pelatihan mereka. Dengan melihat kenyataan ini kedua variabel masih perlu ditingkatkan melalui suatu program dalam rangka meningkatkan kinerja para 
guru Madarasah Tsanawiyah Swasta (MTsS) se-Kota Padang Panjang.

\section{SARAN}

Berdasarkan temuan penelitian ini, maka peneliti mengemukakan beberapa saran sebagai rekomendasi kepada berbagai pihak mengupayakan bimbingan teknis maupun workshop agar kinerja guru, pelatihan dan Kepala Madrasah dapat membina para guru dengan pemberlakuan pelatihan yang konsisten dan terprogram, Pemerintah Kota Padang Panjang melalui Dinas Pendidikan serta Kementrian Agama Kota Padang Panjang diharapkan membuat kebijakan dalam hal pelatihan terhadap guru-guru sehingga dapat mewujudkan kinerja guru yang efektif.

\section{KEPUSTAKAAN ACUAN}

Djama'an, Satori dkk. (2008). Profesi Keguruan. Jakarta: Universitas Terbuka.

Mangkunegara, Anwar Prabu. (2010). Evaluasi Kinerja SDM. Bandung: Refika Aditama.
Marzuki, M.S. (1992). Strategi dan Model Pelatihan. Malang: IKIP Malang. Metode Pelatihan, Kajian Pedesaan secara Partisipatif. (1992). www.deliveri. org

Mulyasa, E. (2009). Menjadi Kepala Sekolah Profesional. Bandung: Rosda Karya.

Nasution, S. (1982). Berbagai Pendekatan dalam Proses Belajar Mengajar. Jakarta: Bina Aksara.

Peraturan Menteri Pendidikan Nasional Republik Indonesia (Permendiknas) No. 16 Tahun 2007 tentang Standar Kompetensi Guru

Sumantri, S. (2000). Pelatihan dan Pengembangan Sumber Daya Manusia. Bandung: Fakultas Psikologi UNPAD. Yamin, Martinis dan Maisah. (2010). Standarisasi Kinerja Guru. Jakarta: Gaung Persada. 